\section{OPEN ACCESS}

Edited by:

Robert James Hayashi,

Washington University School of

Medicine in St. Louis, United States

Reviewed by:

Michael Daniel Keller

Children's National Hospital,

United States

Federico Simonetta,

Geneva University Hospitals

(HUG), Switzerland

*Correspondence:

Patrizia Comoli

pcomoli@smatteo.pv.it

tThese authors have contributed equally to this work

Specialty section:

This article was submitted to Alloimmunity and Transplantation,

a section of the journal

Frontiers in Immunology

Received: 29 May 2020

Accepted: 03 September 2020

Published: 15 October 2020

Citation:

Basso S, Compagno F, Zelini P,

Giorgiani G, Boghen S, Bergami E, Bagnarino J, Siciliano M, Del Fante C,

Luppi $M$, Zecca $M$ and Comoli $P$

(2020) Harnessing T Cells to Control Infections After Allogeneic

Hematopoietic Stem Cell Transplantation.

Front. Immunol. 11:567531.

doi: 10.3389/fimmu.2020.567531

\title{
Harnessing T Cells to Control Infections After Allogeneic Hematopoietic Stem Cell Transplantation
}

\begin{abstract}
Sabrina Basso ${ }^{1,2}$, Francesca Compagno ${ }^{1}$, Paola Zelini ${ }^{1,2}$, Giovanna Giorgiani ${ }^{1}$, Stella Boghen ${ }^{1}$, Elena Bergami ${ }^{1}$, Jessica Bagnarino ${ }^{1,2}$, Mariangela Siciliano ${ }^{2}$, Claudia Del Fante ${ }^{3}$, Mario Luppi ${ }^{4}$, Marco Zecca ${ }^{1+}$ and Patrizia Comoli ${ }^{1,2 * t}$
\end{abstract}

\begin{abstract}
${ }^{1}$ Pediatric Hematology/Oncology, Fondazione Istituto di Ricovero e Cura a Carattere Scientifico Policlinico San Matteo, Pavia, Italy, ${ }^{2}$ Cell Factory, Fondazione Istituto di Ricovero e Cura a Carattere Scientifico Policlinico San Matteo, Pavia, Italy, ${ }^{3}$ Immunohematology and Transfusion Service, Fondazione Istituto di Ricovero e Cura a Carattere Scientifico Policlinico San Matteo, Pavia, Italy, ${ }^{4}$ Section of Hematology, Department of Medical and Surgical Sciences, University of Modena and Reggio Emilia, Azienda Ospedaliero-Universitaria Policlinico, Modena, Italy
\end{abstract}

Dramatic progress in the outcome of allogeneic hematopoietic stem cell transplantation (allo-HSCT) from alternative sources in pediatric patients has been registered over the past decade, providing a chance to cure children and adolescents in need of a transplant. Despite these advances, transplant-related mortality due to infectious complications remains a major problem, principally reflecting the inability of the depressed host immune system to limit infection replication and dissemination. In addition, development of multiple infections, a common occurrence after high-risk allo-HSCT, has important implications for overall survival. Prophylactic and preemptive pharmacotherapy is limited by toxicity and, to some extent, by lack of efficacy in breakthrough infections. T-cell reconstitution is a key requirement for effective infection control after HSCT. Consequently, T-cell immunotherapeutic strategies to boost pathogen-specific immunity may complement or represent an alternative to drug treatments. Pioneering proof of principle studies demonstrated that the administration of donor-derived $T$ cells directed to human herpesviruses, on the basis of viral DNA monitoring, could effectively restore specific immunity and confer protection against viral infections. Since then, the field has evolved with implementation of techniques able to hasten production, allow for selection of specific cell subsets, and target multiple pathogens. This review provides a brief overview of current cellular therapeutic strategies to prevent or treat pathogen-related complications after HSCT, research carried out to increase efficacy and safety, including T-cell production for treatment of infections in patients with virus-naïve donors, results from clinical trials, and future developments to widen adoptive T-cell therapy access in the HSCT setting.

Keywords: multipathogen infection, T cell immunity, T-cell therapy, pathogen specific T cells, Allo-HSCT 


\section{INTRODUCTION}

Dramatic progress in the outcomes of allogeneic hematopoietic stem cell transplantation (allo-HSCT) from alternative sources in pediatric patients has been registered over the past decade, providing a chance to cure the children and adolescents in need of a transplant (1-4). Despite encouraging results, infections are still important causes of morbidity and mortality in immunosuppressed patients following HSCT (5). Viral reactivations predominantly develop within the first 6 months after HSCT. Double-stranded DNA viruses contribute to substantial morbidity, with herpesviruses, adenovirus (AdV) and polyomaviruses $\mathrm{BK}(\mathrm{BKPyV})$ and $\mathrm{JC}(\mathrm{JCPyV})$ as the clinically most relevant infections (5-14). In addition, respiratory viruses and fungal infections are also associated with dismal outcome (15-18).

If the development of single opportunistic infections may have severe consequences in transplant recipients, it has been demonstrated that persistent detection of multiple DNA viruses is frequent after allogeneic HSCT, and had a dose-dependent association with increased mortality (19). Indeed, cumulative viral load AUC in the first 100 days post-HSCT was consistently and independently associated with increased risk for early and late overall mortality and non-relapse mortality (NRM). The effects on NRM do not appear to be direct, as only a small portion of patients succumbed to viral disease. Rather, viremia may cause indirect effects due to increased production of proinflammatory and immunomodulatory cytokines that contribute to the pathogenesis of HSCT complications $(20,21)$.

In recent years treatment of viral complications after HSCT has improved in part because of the introduction of new antivirals, and in part from the preemptive use of antiviral agents at the onset of viremia. The latter is successful thanks to the widespread use of surveillance by molecular detection methods $(22,23)$. Likewise, the ability to recognize invasive fungal disease while in the early stages, by means of imaging and peripheral blood antigen measurement, coupled with assessment of antifungal immune responses, allowed for prompt treatment and amelioration of outcome (24). Despite advances in prophylactic and preemptive pharmacotherapy, antipathogen therapeutics are limited by toxicity, in particular myelosuppression and renal injury, and to some extent by a lack of efficacy in breakthrough infections (25).

The development of infections in the post-transplant period principally reflects the inability of the absent/depressed host immune system to limit pathogen replication and dissemination; loss of $\mathrm{T}$ cell function is central to this effect (26-28). Tcell reconstitution is a key requirement for effective infection control following HSCT, and factors that influence the speed

Abbreviations: allo-HSCT, allogeneic hematopoietic stem cell transplantation; $\mathrm{AdV}$, adenovirus; BKPyV, polyomavirus BK; JCPyV, polyomavirus JC; CMV, Cytomegalovirus; HHV6, human herpes virus 6; EBV, Epstein-Barr virus; PTLD, Post-transplant lymphoproliferative disease; HC, hemorrhagic cystitis; PML, progressive multifocal leukoencephalopathy; UD, unrelated donor; NRM, non-relapse mortality; DLI, donor lymphocyte infusions; CTL, Cytotoxic T lymphocytes; a/cGVHD, acute/chronic graft vs. host disease; VSTs, virus-specific $\mathrm{T}$ cells; CI: calcineurin inhibitors. of T-cell recovery also impact the risk of infection in this period (27). A high degree of HLA mismatch between donor and recipient reduces the efficacy of immune surveillance due to poor epitope recognition, and increases the risk of inducing alloimmune responses, thus requiring stronger immunosuppression to prevent and treat graft-vs.-host disease. Likewise, delayed immune recovery is associated with T-cell depletion of the graft before transplantation.

Given the central role of pathogen-specific $\mathrm{T}$ cells in infection surveillance, immunotherapeutic strategies to accelerate reconstitution of pathogen-specific immunity and to hasten T cell recovery after HSCT represent a compelling alternative to drug treatments $(14,23,27,29-36)$. Moreover, preventive strategies may be expanded toward the use of virus-specific $\mathrm{T}$ cell assays to help identify patients at risk and to tailor therapeutic intervention $(23,37-40)$.

Here, we discuss the clinical achievements of T-cell therapy for infections, describe the impact of technical developments on clinical applicability, and give indications on future directions to broaden access.

\section{CELL THERAPY FOR INFECTIONS AFTER HSCT}

\section{Donor Lymphocyte Infusions}

The use of donor lymphocyte infusions (DLI) derived from seropositive stem cell donors is an effective salvage therapy for viral infections in HSCT recipients prior to T-cell recovery, but the risk of potentially severe acute or chronic graft-vs.-host disease (GVHD) is a concern (41). In order to reduce the risks derived from alloreactivity associated with DLI, non-specific $\mathrm{T}$ cells transduced with a retroviral construct containing suicide genes, to induce susceptibility to drug mediated lysis in case of development of alloreactive response, have been employed with success (42). The use of DLI modified with the iCasp9 cellsuicide system in a small cohort of children transplanted for acute leukemia demonstrated the potential advantages in terms of rapid and consistent cell removal in case of GVHD development (43).

\section{Pathogen-Specific T Cells: Production Protocols}

An alternate strategy consists in delivering infectious antigenspecific $\mathrm{T}$ cells selected by cell culture or by sorting. A major breakthrough was achieved by the adoptive transfer of virusspecific cytotoxic T lymphocytes (CTL) reactivated from the peripheral blood of HSCT donors as prophylaxis/treatment against CMV disease or EBV-positive post-transplant lymphoproliferative disease in patients given T-cell depleted, HLA-disparate, unrelated HSCT $(32,33)$. This approach has been successful in preventing and treating CMV and EBV infectious complications after T-cell depleted haplo-HSCT, both in the pediatric and adult setting, while limiting the risk of inducing $\operatorname{GVHD}(27,30)$.

Initially, protocols for production of virus-specific $\mathrm{T}$ cells (VSTs) were all based on complex procedures of stimulation and in vitro expansion, leading to a final product of polyclonal $\mathrm{T}$ cells 
with broad specificity. One of the main advantages of ex vivo differentiation is the ability to overcome the hurdle of obtaining substantial numbers of VSTs from donors with low-frequency memory $\mathrm{T}$ cells for a given antigen, and the ability to reduce alloreactivity by continuous stimulation with viral antigens. This is counterbalanced by production times, that can be as long as 3-8 weeks, limiting its usefulness in patients with urgent clinical need and running the risk of inducing cellular exhaustion. The latter does not seem to be a major obstacle, however, as donor gene-marked EBV-specific T cells cultured for 4-6 weeks were able to reconstitute T cell memory in HSCT recipients, and were detected as late as 9 years after administration in patients with viral reactivation (44). The availability of synthetic peptide pools, novel techniques, and progress in culture reagents and vessels has allowed reduction in production time, bringing it to $<2$ weeks (45-47).

A valid alternative to cell culture is direct selection of pathogen-specific $\mathrm{T}$ cells by using viral peptide HLA class I multimers conjugated to magnetic beads (48), or stimulation with viral peptides followed by the IFN-gamma capture assay with magnetic beads $(34,49,50)$. The latter has an important advantage over multimers, as it allows selection of CD4+ in addition to $\mathrm{CD} 8+$ virus-specific $\mathrm{T}$ cells, guaranteeing sustained long-term immune protection (51). Direct selection allows rapid production of VSTs, but it is generally feasible only for pathogens inducing an ample memory T cell pool, such as for CMV or EBV, and requires a leukapheretic procedure to obtain starting cellular material. In addition, it is not an option for virus-naïve subjects.

\section{Pathogen-Specific T Cells: Clinical Results for EBV, CMV, ADV, and Aspergillosis}

Since the early clinical trials for EBV and CMV, the prophylactic, preemptive and curative use of $\mathrm{T}$ cell therapy for infection has expanded, due to the reported high rates of response and low toxicity (Tables 1, 2). The efficacy of virus-specific adoptive cellular therapy has been difficult to assess, due to the difficulties of running large prospective multicenter clinical trials, and heterogeneity of reported studies in study design, cell product characteristics and treated cohorts. However, prophylaxis/preemptive treatment of EBV PTLD after HSCT has shown more than $95 \%$ response rate in the 107 patients treated with cultured single VSTs $(23,33,44,52,53,85)$. Treatment of overt disease was successful in over $80 \%$ of the patients treated for PTLD $(52,54-56,85)$ or CMV viremia or disease $(32,35,58-$ 62 ), with little toxicity almost exclusively limited to a $1-10 \%$ rate of GVHD. The rate of GVHD was generally lower in patients treated for EBV infection/disease, probably due to a prevalence of CD8+ T cells in the infused EBV-specific CTLs, compared to a larger portion of $\mathrm{CD} 4+\mathrm{T}$ cells present in CMV-specific products. Directly selected cellular products employed in more recent studies have proven equally effective in reconstituting post-transplant immunity, but rates of clinical responses were slightly lower, reportedly $60 \%$ in patients with PTLD $(50,57)$ and $70 \%$ in patients treated for $\operatorname{CMV}(48,49,63,65,73)$ or $\mathrm{ADV}$ $(34,66-68,86)$ viremia or disease. Moreover, the incidence of new onset or exacerbation of GVHD was higher at 15\%, likely due to residual, potentially alloreactive, T cells in the product. Clearly, as head-to-head controlled studies with cell products obtained by culture vs. direct selection have not yet been performed, the reported efficacy and safety rates of the different strategies may be confounded by the variety of protocols and clinical settings.

Attempts at reconstituting cellular immune responses to fungal antigens, and controlling invasive aspergillosis (IA) in HSCT recipients have been also successful. Pioneer work showed the feasibility to expand $\mathrm{T}$ cell clones directed to aspergillus conidia and devoid of alloreactivity, that were employed to treat IA in 10 recipients of haplo-HSCT (35). Emergence of circulating pathogen-specific T cells were associated with control of Aspergillus antigenemia and infectious mortality.

\section{Pathogen-Specific T Cells: Preliminary Clinical Results for PyVs and HHV6}

Cell therapy has been employed also for the treatment of other infections, such as polyomaviruses and HHV6. Although very preliminary, initial experiences with $\mathrm{BKPyV}$-specific cells are promising $(36,69)$, as 13 of 14 patients treated for BKVassociated hemorrhagic cystitis within a clinical trial of thirdparty banked multivirus-specific $\mathrm{T}$ cell therapy in allogeneic HSCT experienced complete resolution of gross hematuria within 1-2 months (36). Of the two patients treated for virusrelated nephropathy, one responded to treatment by ameliorating renal function. In $50 \%$ of the treated patients, an increase in $\mathrm{BKPyV}$-specific immune response was observed. The main side effects were recurrence or new onset of GVHD in 16\% of the whole study cohort and transient hydronephrosis and a decrease in renal function in one patient who received VSTs as treatment for BKPyV HC. The latter, associated with a concomitant bacterial urinary tract infection, could have also been due to lysis of infected cells in renal tubular cells.

Four patients, reported in two studies, were treated for JCPyV PML $(14,74)$. One pediatric HSCT recipient received donor JCPyV-specific T cells, that was associated with reconstitution of specific viral immunity, clearance of viral DNA from the cerebrospinal fluid (CSF) and disease control with remarkable neurological improvement, in the absence of immune reconstitution syndrome (14). Three patients were treated with third-party allogeneic BKPyV-specific T cells, based on reported observations of a certain degree of cross-reactivity between PyV BK and JC due to high homology (74). The CBT recipient fully recovered. In the other two patients, viral load was cleared or reduced in CSF, with the patients showing neurologic improvement with residual deficit in one case, and disease progression in the other. Two of the patients had immune reconstitution syndrome. Phase I or I/II trials are currently underway.

Two patients with HHV6 infections were treated with T cells specific for U11, U14, and U90 within a clinical trial of thirdparty banked multivirus-specific $\mathrm{T}$ cell therapy in allogeneic HSCT (36). One patient was treated for HHV6 encephalitis and the other for HHV6 viremia with fevers and symptoms of bone marrow suppression, including neutropenia. Both patients showed decreased viral load and normalization of clinical disease. 
TABLE 1 | Published trials using single pathogen-specific T cells.

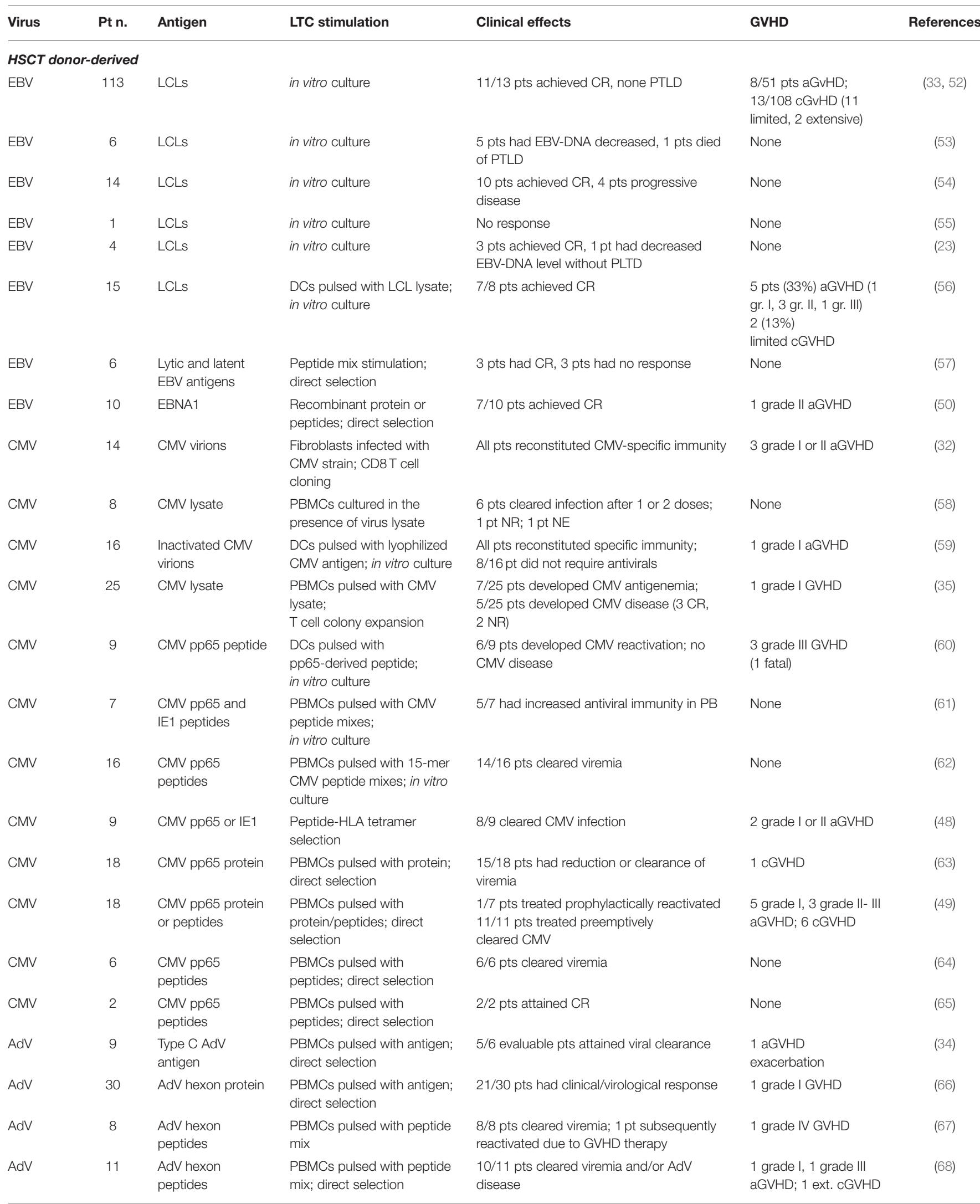


TABLE 1 | Continued

\begin{tabular}{|c|c|c|c|c|c|c|}
\hline Virus & Pt $\mathbf{n}$. & Antigen & LTC stimulation & Clinical effects & GVHD & References \\
\hline BKPyV & 1 & $\begin{array}{l}\text { BKPyV VP1 and } \\
\text { LT }\end{array}$ & $\begin{array}{l}\text { PBMCs pulsed with } \\
\text { Peptides; direct selection }\end{array}$ & 1 pt cleared infection and had CR & None & (69) \\
\hline JCPyV & 1 & JCPyV VP1 and LT & $\begin{array}{l}\text { PBMCs pulsed with } \\
\text { overlapping peptides; } \\
\text { in vitro culture }\end{array}$ & 1 pt cleared infection and had CR & None & (14) \\
\hline $\begin{array}{l}\text { Aspergillus } \\
\text { f. }\end{array}$ & 10 & Fungal conidia & $\begin{array}{l}\text { PBMCs pulsed with conidia; } \\
\text { T cell colony expansion }\end{array}$ & 9/10 pts attained CR & None & (35) \\
\hline \multicolumn{7}{|c|}{ Third-party donor-derived } \\
\hline EBV & 33 & LCLs & in vitro culture & $\begin{array}{l}14 \text { pts attained EBV CR, } 3 \text { pts had PR, } 16 \\
\text { pts no response at } 6 \mathrm{~m}\end{array}$ & None & $(70)$ \\
\hline EBV & 5 & LCLs & in vitro culture & $\begin{array}{l}4 \text { pts attained EBV CR, } 1 \text { pts progressive } \\
\text { disease }\end{array}$ & None & $(71)$ \\
\hline EBV & 33 & LCLs & in vitro culture & $\begin{array}{l}\mathrm{CR} \text { or PR was achieved in } 68 \% \text { of HSCT } \\
\text { recipients. For patients who achieved } \\
\text { CR/PR or SD after cycle } 1,1 \text { y OS was } \\
88.9 \%\end{array}$ & 1 grade I skin aGvHD & $(72)$ \\
\hline EBV & 1 & EBV peptides & $\begin{array}{l}\text { Peptide-HLA multimer } \\
\text { selection }\end{array}$ & $\begin{array}{l}\text { CR after } 9 \mathrm{~m} \text {, recurrence then response to } \\
\text { 2nd infusion }\end{array}$ & None & (73) \\
\hline CMV & 5 & CMV pp65 & $\begin{array}{l}\text { Peptide-HLA multimers } \\
\text { selection }\end{array}$ & 4/5 pts attained viremia clearance & None & (73) \\
\hline JCPyV & 3 & $\begin{array}{l}\text { BKPyV VP1, VP2, } \\
\text { VP3, ST and LT } \\
\text { peptides }\end{array}$ & $\begin{array}{l}\text { PBMCs pulsed with } \\
\text { overlapping peptides; } \\
\text { in vitro culture }\end{array}$ & $\begin{array}{l}2 / 3 \text { pts cleared infection and CR ( } 1 \text { with } \\
\text { sequelae) }\end{array}$ & 1 IRIS & (74) \\
\hline
\end{tabular}

Experience With Multivirus-Specific T Cells Most of the cell therapy experience regards treatment of CMV and EBV infections. However, patients with multiple infections have a worse outcome (19), and in the pediatric population or in recipients of haplo-HSCT, the impact of other viral infections, such as adenovirus or HHV6, has important implications for overall survival $(8,87)$. Thus, the possibility to produce in a single process VSTs specific for multiple viruses is crucial for progress in the field. Proof of principle studies have been conducted, that demonstrated feasibility and preliminary efficacy of controlling viral reactivation after allogeneic HSCT by multivirus-specific VST of HSCT donor or third-party origin, obtained by exvivo stimulation with virus-transduced EBV lymphoblastoid cell lines $(75-77,82,84)$, dendritic cells nucleofected with plasmids encoding for viral proteins or pulsed with viral peptides $(78,79$, 81 ), or directly with 15 -mer peptide pools from immunogenic viral proteins $(36,80)$ (Table 2).

Prophylactic or curative administration in a total of 82 patients treated with HSCT donor-derived cells and 96 thirdparty donor cells showed responses in the range of 80-95 and $70-100 \%$, respectively (Table 2 ). Clinical benefit could be demonstrated also in patients treated for multiple coincident infections (36). Although clinical responses have been registered for all targeted viruses, evidence of $\mathrm{T}$ cell expansion in the peripheral blood of treated patients is mainly seen for viruses with large memory cell pools, such as CMV and EBV, while, due to the small size of their memory compartment, immune responses to AdV or HHV6 do not seem to be boosted unless a reactivation is underway. Indeed, antigenic competition that will ensue when engaging multiple target antigens within the same culture, will determine a preferential expansion of $\mathrm{T}$ cells recognizing the immunodominant specificities of viruses with large memory cell pools. This will impact on the composition of multivirus-specific $\mathrm{T}$ cell products, as $\mathrm{T}$ lymphocytes directed to certain non-immunodominant targets, as well as to viruses with low-frequency memory $\mathrm{T}$ cells, will be underrepresented, and it may also ultimately impact on efficacy.

\section{CURRENT LIMITATIONS OF T CELL THERAPY FOR INFECTIONS}

There are several hurdles that concur in limiting the use and the clinical efficacy of pathogen-targeted $\mathrm{T}$ cell therapy. First of all, production of pathogen-targeted $\mathrm{T}$ cells have been so far mostly confined to a relatively small numbers of academic centers with required Good Manufacturing Practice (GMP) expertise and facilities, that have limited ability to provide widespread access to these therapies. Moreover, for some patient categories, such as recipients of HSCT from pathogennaïve donors, expansion of dedicated $\mathrm{T}$ cell products may not be feasible.

In addition, the appropriate timing and schedule for $\mathrm{T}$ cell delivery, as well as $\mathrm{T}$ cell dose or optimal cell product composition, have not been yet established, due to the presence of many different confounding variables, such as transplant ad infectious disease setting, use of in vitro or in vivo T-cell depletion, and immunosuppressive regimens. These issues will have to be addressed in future controlled comparative trials. 
TABLE 2 | Published trials using multivirus-specific T cells.

\begin{tabular}{|c|c|c|c|c|c|c|}
\hline Virus & Pt n. & Antigen & LTC stimulation & Clinical effects & GVHD & References \\
\hline \multicolumn{7}{|c|}{ HSCT donor-derived } \\
\hline $\begin{array}{l}\text { AdV, CMV and } \\
\text { EBV }\end{array}$ & 26 & $\begin{array}{l}\text { AdV5; CMV pp65; } \\
\text { EBV-LCL }\end{array}$ & $\begin{array}{l}\text { LCLs transduced with } \\
\text { Ad5f35-pp65 }\end{array}$ & $\begin{array}{l}\text { 6/6 with EBV cleared infection; } \\
5 / 6 \text { with AdV cleared infection; 10/11 CMV } \\
\text { cleared infection and } 1 \text { pt progressed } \\
\text { despite VSTs/pharmacotherapy }\end{array}$ & 2 grade I GVHD & $(75,76)$ \\
\hline AdV and EBV & 14 & AdV5; EBV-LCL & $\begin{array}{l}\text { LCLs transduced with } \\
\text { Ad5f35 vector }\end{array}$ & $\begin{array}{l}11 \text { pts treated as prophylaxis remain } \\
\text { negative; } \\
2 / 3 \text { pts with } A d V \text { cleared infection }\end{array}$ & 3 grade I GVHD & (77) \\
\hline CMV and EBV & 3 & $\begin{array}{l}\text { CMV pp65; EBV } \\
\text { IE1 and LMP2 }\end{array}$ & DCs pulsed with peptides & $\begin{array}{l}2 \text { pts cleared infection; } 1 \mathrm{pt} \text { treated as } \\
\text { prophylaxis remains negative }\end{array}$ & 1 grade I GVHD & (78) \\
\hline $\begin{array}{l}\text { AdV, CMV and } \\
\text { EBV }\end{array}$ & 10 & $\begin{array}{l}\text { AdV5 Hexon and } \\
\text { Penton; } \\
\text { CMV IE1 e pp65; } \\
\text { EBV LMP2 } \\
\text { and BZLF1 }\end{array}$ & $\begin{array}{l}\text { DCs nucleofected with } \\
\text { plasmids encoding for viral } \\
\text { antigens }\end{array}$ & 8/10 pt: complete virologic responses & $\begin{array}{l}1 \text { skin rash due to } \\
\text { GVHD or BKPyV } \\
\text { infection }\end{array}$ & (79) \\
\hline $\begin{array}{l}\text { AdV, CMV, EBV, } \\
\text { and VZV }\end{array}$ & 10 & $\begin{array}{l}\text { AdV5; CMV pp65; } \\
\text { EBV EBNA1 and } \\
\text { LMP; VZV vaccine }\end{array}$ & $\begin{array}{l}\text { Ad5f35-pp65, } \\
\text { Ad5f35-EBNA1/LMP, } \\
\text { commercial VZV vaccine }\end{array}$ & $\begin{array}{l}6 \text { pts with CMV reactivation, only } 1 \text { receving } \\
\text { antiviral therapy; } \\
\text { no EBV, AdV or VZV reactivation }\end{array}$ & $\begin{array}{l}1 \text { grade II GVHD } \\
1 \text { grade III GVHD }\end{array}$ & (81) \\
\hline $\begin{array}{l}\text { AdV, CMV and } \\
\text { EBV }\end{array}$ & 3 & $\begin{array}{l}\text { AdV5; CMV pp65; } \\
\text { EBV-LCL }\end{array}$ & $\begin{array}{l}\text { LCLs transduced with } \\
\text { AdV5-pp65 vector }\end{array}$ & $\begin{array}{l}1 \mathrm{pt} \text { cleared infection. } \\
2 \text { pts treated as prophylaxis } \\
\text { remains negative }\end{array}$ & None & (82) \\
\hline $\begin{array}{l}\text { CMV, AdV and } \\
\text { EBV }\end{array}$ & 7 & $\begin{array}{l}\text { Various source } \\
\text { antigens }\end{array}$ & $\begin{array}{l}\text { T cell culture; in } 1 \text { case, } \\
\text { streptamer selection }\end{array}$ & $\begin{array}{l}2 \text { pts with EBV attained CR; } \\
5 \text { pts with CMV:2 CR, } 2 \text { PR and } 1 \text { failure }\end{array}$ & $\begin{array}{l}1 \text { grade I GVHD } \\
1 \text { grade II GVHD }\end{array}$ & (83) \\
\hline $\begin{array}{l}\text { AdV, BKPyV, } \\
\text { CMV, EBV and } \\
\text { HHV6 }\end{array}$ & 38 & $\begin{array}{l}\text { AdV5 Hexon; } \\
\text { BKPyV LT + VP1; } \\
\text { CMV IE1 + pp65; } \\
\text { EBV LMP2 + } \\
\text { EBNA1 + BZLF1; } \\
\text { HHV6 U11 + U14 } \\
+ \text { U90 }\end{array}$ & $\begin{array}{l}\text { Peptide pools from } \\
\text { immunodominant antigens }\end{array}$ & $\begin{array}{l}\text { 3/3 pts with EBV attained CR; } \\
\text { 8/10 pts with AdV attained CR or PR; } \\
\text { 20/21 pts with CMV attained CR or PR; } \\
\text { 19/21 pts with BKV attained CR or PR } \\
\text { 3/3 pts with HHV6 attained CR or PR; }\end{array}$ & $\begin{array}{l}2 \text { grade I GVHD de } \\
\text { novo; } \\
4 \text { grade I-III } \\
\text { recurrent GVHD }\end{array}$ & (36) \\
\hline
\end{tabular}

Finally, HSCT recipients treated with steroids or calcineurin inhibitors (CI) for GVHD are among those at highest risk of infectious complications. However, in these patients cell therapy has the least chance of success, as steroids have a direct cytopathic effect, and CI impair $\mathrm{T}$ cell expansion potential. Recently, preclinical studies have demonstrated the feasibility of producing pathogen-specific single or multivirus-specific $\mathrm{T}$ cells resistant to steroids (88), or to CI $(89,90)$, by genetic modification, and clinical studies are underway to assess safety and preliminary efficacy.

\section{IMPROVING ACCESS TO CELL THERAPY Manufacturing VST From Antigen-Seronegative Donors}

Pediatric recipients who reactivate viral infections after HSCT from virus-naive stem cell donors are at high risk of developing complications. It has been shown that it is possible to prime tumor- or virus-specific responses by delivering viral antigens presented by professional antigen-presenting cells in the presence of activating/homeostatic cytokines $(91,92)$. Stimulation by 
dendritic cells pulsed with EBV LCL, or stimulation with EBVLCL, either with subsequent selection of CD25-positive Tcells, or in the presence of cytokines, such as IL-7 and/or IL12, have all been described (92-94). The latter approach was demonstrated effective when employed to expand EBV-CTL that were successfully infused in vivo to treat a disseminated PTLD, unresponsive to multiple courses of rituximab and chemotherapy, in a pediatric recipient of unrelated HSCT from a EBV-seronegative donor (95).

Multivirus (CMV, EBV, and adenovirus)-specific T-cells have been activated and expanded from $\mathrm{CB}$, by stimulation with $\mathrm{DC}$ or LCL pulsed with a CMV-pp65 overlapping peptide library, in the presence of IL-7, IL-12, and IL-15. The primed cells were only able to recognize atypical pp65 epitopes, but when administered to $\mathrm{CBT}$ recipients mediated CMV-directed activity in one patient experiencing viral reactivation (82).

\section{Third-Party Banked VST}

Donor-derived VST infusions are not always feasible in clinical practice, due to impossibility to obtain starting material from the donor, as in UD or CB transplantation. Moreover, rapid disease progression may not allow the time required for dedicated production. A practical approach to overcome these issues is to employ banked, HLA-typed VST obtained from healthy donors, selected for a candidate recipients on the basis of the most closely matched line with specific activity against a given pathogen through one or more shared HLA epitopes.

Theoretically, third-party VST could have short persistence in vivo, with limited clinical benefit, as the partial HLA disparity may induce allorecognition by recipient $\mathrm{T}$ cells. Alloresponses by infused third-party cells may, in turn, cause GVHD. So far, results have been encouraging, with only one report of bystanderinduced liver GVHD (96). Seminal data were obtained in solid organ-transplanted patients with EBV PTLD: the response rate in the 33 patients enrolled in the first phase II trial, that included 6 HSCT recipients, was $52 \%$ at 6 months (70). Since then, thirdparty VST have been effectively used also in the setting of HSCT $(36,62,71-73,83,84,96)$, demonstrating that the approach is feasible without inducing a higher rate of GVHD than HSCT donor-derived VST, while producing significant clinical responses. A recent study demonstrated safety and efficacy of third-party rapidly-generated single-culture donor VST that recognized 12 antigens from EBV, AdV, CMV, BKPyV, and HHV6 in 38 patients enrolled in a phase II trial. Importantly, clinical benefit could be demonstrated also in seven patients treated for multiple coincident infections (36). VST banks recently created include products characterized for epitope specificity and HLA

\section{REFERENCES}

1. Zecca M, Strocchio L, Pagliara D, Comoli P, Bertaina A, Giorgiani G, et al. HLA-haploidentical $\mathrm{T}$ cell-depleted allogeneic hematopoietic stem cell transplantation in children with Fanconi anemia. Biol Blood Marrow Transplant. (2014) 20:571-6. doi: 10.1016/j.bbmt.2014.01.015

2. Locatelli F, Bernardo ME, Bertaina A, Rognoni C, Comoli P, Rovelli A, et al. Efficacy of two different doses of rabbit anti-T-lymphocyte restriction elements, to further refine selection of the best VST for each patient.

\section{CONCLUDING REMARKS}

It is likely that VSTs will have an increasing role as therapeutics in the prevention and management of viral infections after HSCT, due to high rate of response and limited toxicity profile observed in reported studies. However, many issues are still open, and will need to be addressed in future studies, such as the most suitable predictive markers for response, the identification of patients at risk of treatment failure, optimal treatment schedule in different clinical settings, and choosing adequate end-point for future clinical trials.

The majority of subjects treated to date with cell therapy for infections have received dedicated donor $\mathrm{T}$ cells, but this approach may not be best suited for widespread costeffective access, since these are personalized medicines that are produced on-demand through a complex and costly supply chain. The development of new methodologies to obtain rapid manufacture of third-party $\mathrm{T}$ cells, refinement of strategies to allow adequate selection of the "best VST" for each candidate patient and the possibility to widen applicability to setting beyond HSCT, has prompted considerable interest from the industry to bring to the market third-party cellular therapies. This process will allow to benefit patients through better $\mathrm{T}$ cell therapy access.

\section{AUTHOR CONTRIBUTIONS}

SBa, FC, PZ, GG, SBo, EB, JB, MS, CDF, ML, MZ, and PC all participated in writing the manuscript. $\mathrm{SBa}, \mathrm{MZ}$, and $\mathrm{PC}$ coedited the final version of the manuscript. All of the authors have read and approved the final manuscript.

\section{FUNDING}

This work was supported by grants from the Fondazione Regionale per la Ricerca Biomedica (PC), Fondazione Istituto di Ricovero e Cura a Carattere Scientifico (IRCCS) Policlinico San Matteo [Ricerca Corrente 08069113 and 08069119 (PC); Ricerca Corrente 08045818 (MZ); Ricerca Corrente 08071519 (SBa)], Fondazione Just Italia (PC), Associazione Italiana per la Ricerca sul Cancro (AIRC), Milan, Italy (IG 20624-2018) (ML), and the "Charity Dinner Initiative" in memory of Dr. A. Fontana for Associazione Italiana Lotta alle Leucemie, Linfoma e Mieloma (AIL) - Sezione 'Luciano Pavarotti'- Modena-ONLUS (ML). globulin to prevent graft-versus-host disease in children with haematological malignancies transplanted from an unrelated donor: a multicentre, randomised, open-label, phase 3 trial. Lancet Oncol. (2017) 18:1126-36. doi: 10.1016/S1470-2045(17)30417-5

3. Bertaina A, Zecca M, Buldini B, Sacchi N, Algeri M, Saglio F, et al. Unrelated donor vs HLA-haploidentical $\alpha / \beta$ T-cell- And Bcell-depleted HSCT in children with acute leukemia. Blood. (2018) 132:2594-607. doi: 10.1182/blood-2018-07-861575 
4. Rocha V. Umbilical cord blood cells from unrelated donor as an alternative source of hematopoietic stem cells for transplantation in children and adults. Semin Hematol. (2016) 53:237-45. doi: 10.1053/j.seminhematol.2016. 08.002

5. Boeckh M, Erard V, Zerr D, Englund J. Emerging viral infections after hematopoietic cell transplantation. Pediatr Transplant. (2005) 7:4854. doi: 10.1111/j.1399-3046.2005.00442.x

6. Boeckh $M$, Ljungman $P$. How we treat cytomegalovirus in hematopoietic cell transplant recipients. Blood. (2009) 113:57119. doi: 10.1182/blood-2008-10-143560

7. Hiwarkar P, Kosulin K, Cesaro S, Mikulska M, Styczynski J, Wynn R, et al. Management of adenovirus infection in patients after haematopoietic stem cell transplantation: state-of-the-art and real-life current approach: a position statement on behalf of the infectious diseases working party of the European society of blood and marrow transplantation. Rev Med Virol. (2018) 28:e1980. doi: 10.1002/rmv.1980

8. Zecca M, Wynn R, Dalle JH, Feuchtinger T, Vainorius E, Brundage TM, et al. Association between adenovirus viral load and mortality in pediatric alloHCT recipients: the multinational advance study. Bone Marrow Transplant. (2019) 54:1632-42. doi: 10.1038/s41409-019-0483-7

9. Heslop HE. How I treat EBV lymphoproliferation. Blood. (2009) 114:40028. doi: 10.1182/blood-2009-07-143545

10. Styczynski J, van der Velden W, Fox CP, Engelhard D, de la Camara $\mathrm{R}$, Cordonnier $\mathrm{C}$, et al. Management of Epstein-Barr virus infections and post-transplant lymphoproliferative disorders in patients after allogeneic hematopoietic stem cell transplantation: sixth European conference on infections in leukemia (ECIL-6) guidelines. Haematologica. (2016) 101:80311. doi: 10.3324/haematol.2016.144428

11. Abudayyeh A, Hamdi A, Lin H, Abdelrahim M, Rondon G, Andersson BS, et al. Symptomatic BK virus infection is associated with kidney function decline and poor overall survival in allogeneic hematopoietic stem cell recipients. Am J Transplant. (2016) 16:1492-502. doi: 10.4172/2161-0959.C1.027

12. Hirsch HH. BK virus: opportunity makes a pathogen. Clin Infect Dis. (2005) 41:354-60. doi: 10.1086/431488

13. Imlay $H$, Xie H, Leisenring WM, Duke ER, Kimball LE, Huang ML, et al. Presentation of BK polyomavirus-associated hemorrhagic cystitis after allogeneic hematopoietic cell transplantation. Blood Adv. (2020) 4:61728. doi: 10.1182/bloodadvances.2019000802

14. Balduzzi A, Lucchini $G$, Hirsch $\mathrm{HH}$, Basso S, Cioni M, Rovelli A, et al. Polyomavirus JC-targeted T-cell therapy for progressive multiple leukoencephalopathy in a hematopoietic cell transplantation recipient. Bone Marrow Transplant. (2011) 46:987-92. doi: 10.1038/bmt.2010.221

15. Waghmare A, Englund JA, Boeckh M. How I treat respiratory viral infections in the setting of intensive chemotherapy or hematopoietic cell transplantation. Blood. (2016) 127:2682-92. doi: 10.1182/blood-2016-01-6 34873

16. Piralla A, Zecca M, Comoli P, Girello A, Maccario R, Baldanti F. Persistent rhinovirus infection in pediatric hematopoietic stem cell transplant recipients with impaired cellular immunity. J Clin Virol. (2015) 67:3842. doi: 10.1016/j.jcv.2015.03.022

17. Kontoyiannis DP, Marr KA, Park BJ, Alexander BD, Anaissie EJ, Walsh TJ, et al. Prospective surveillance for invasive fungal infections in hematopoietic stem cell transplant recipients, 2001-2006: overview of the TransplantAssociated Infection Surveillance Network (TRANSNET) Database. Clin Infect Dis. (2010) 50:1091-100. doi: 10.1086/651263

18. Lehrnbecher $T$. The clinical management of invasive mold infection in children with cancer or undergoing hematopoietic stem cell transplantation. Expert Rev Anti Infect Ther. (2019) 17:489-99. doi: 10.1080/14787210.2019.1626718

19. Hill JA, Mayer BT, Xie H, Leisenring WM, Huang ML, Stevens-Ayers $\mathrm{T}$, et al. The cumulative burden of double-stranded DNA virus detection after allogeneic HCT is associated with increased mortality. Blood. (2017) 129:2316-25. doi: 10.1182/blood-2016-10-748426

20. Schots R, Kaufman L, Van Riet I, Othman TB, De Waele M, Van Camp B, et al. Proinflammatory cytokines and their role in the development of major transplant-related complications in the early phase after allogeneic bone marrow transplantation. Leukemia. (2003) 17:1150-6. doi: 10.1038/sj.leu.2402946

21. Nichols WG, Corey L, Gooley T, Davis C, Boeckh M. High risk of death due to bacterial and fungal infection among cytomegalovirus (CMV)-seronegative recipients of stem cell transplants from seropositive donors: evidence for indirect effects of primary CMV infection. J Infect Dis. (2002) 185:27382. doi: $10.1086 / 338624$

22. Locatelli F, Percivalle E, Comoli P, Maccario R, Zecca M, Giorgiani G, et al. Human cytomegalovirus (HCMV) infection in paediatric patients given allogeneic bone marrow transplantation: role of early antiviral treatment for HCMV antigenaemia on patients' outcome. Br J Haematol. (1994) 88:6471. doi: 10.1111/j.1365-2141.1994.tb04978.x

23. Comoli P, Basso S, Zecca M, Pagliara D, Baldanti F, Bernardo ME, et al. Preemptive therapy of EBV-related lymphoproliferative disease after pediatric haploidentical stem cell transplantation. Am J Transplant. (2007) 7:164855. doi: 10.1111/j.1600-6143.2007.01823.x

24. Potenza L, Barozzi P, Vallerini D, Bosco R, Quadrelli C, Mediani L, et al. Diagnosis of invasive aspergillosis by tracking aspergillus-specific $\mathrm{T}$ cells in hematologic patients with pulmonary infiltrates. Leukemia. (2007) 21:57881. doi: 10.1038/sj.leu.2404504

25. Tomblyn M, Chiller T, Einsele H, Gress R, Sepkowitz K, Storek J, et al. Guidelines for preventing infectious complications among hematopoietic cell transplantation recipients: a global perspective Biol Blood Marrow Transplant. (2009) 15:1143-238. doi: 10.1016/j.bbmt.2009.06.019

26. Moss P, Rickinson A. Cellular immunotherapy for viral infection after HSC transplantation. Nat Rev Immunol. (2005) 5:9-20. doi: 10.1038/nri1526

27. Leen AM, Heslop HE, Brenner MK. Antiviral T-cell therapy. Immunol Rev. (2014) 258:12-29. doi: 10.1111/imr.12138

28. Sester M, Leboeuf C, Schmidt T, Hirsch HH. The "ABC” of virus-specific $\mathrm{T}$ cell immunity in solid organ transplantation. Am J Transplant. (2016) 16:1697-706. doi: 10.1111/ajt.13684

29. Roddie C, Peggs KS. Immunotherapy for transplantation-associated viral infections. J Clin Invest. (2017) 127:2513-22. doi: 10.1172/JCI90599

30. Bollard CM, Heslop HE. T cells for viral infections after allogeneic hematopoietic stem cell transplant. Blood. (2016) 127:3331-40. doi: 10.1182/blood-2016-01-628982

31. Comoli P, Zecca M, Maccario R. Immunotherapy against EBVlymphoma in recipients of HSCT. Expert Rev Hematol. (2010) 3:625-32. doi: 10.1586/ehm.10.56

32. Walter EA, Greenberg PD, Gilbert MJ, Finch RJ, Watanabe KS, Thomas ED, et al. Reconstitution of cellular immunity against cytomegalovirus in recipients of allogeneic bone marrow by transfer of T-cell clones from the donor. $N$ Engl J Med. (1995) 333:1038-44. doi: 10.1056/NEJM199510193331603

33. Rooney CM, Smith CA, Ng CY, Loftin S, Li C, Krance RA, et al Use of gene-modified virus-specific $\mathrm{T}$ lymphocytes to control Epstein-Barr-virusrelated lymphoproliferation. Lancet. (1995) 345:9-13. doi: 10.1016/S0140-6736(95)91150-2

34. Feuchtinger T, Matthes-Martin S, Richard C, Lion T, Fuhrer M, Hamprecht K, et al. Safe adoptive transfer of virus-specific T-cell immunity for the treatment of systemic adenovirus infection after allogeneic stem cell transplantation. $\mathrm{Br}$ J Haematol. (2006) 134:64-76. doi: 10.1111/j.1365-2141.2006.06108.x

35. Perruccio K, Tosti A, Burchielli E, Topini F, Ruggeri L, Carotti A, et al. Transferring functional immune responses to pathogens after haploidentical hematopoietic transplantation. Blood. (2005) 106:4397406. doi: 10.1182/blood-2005-05-1775

36. Tzannou I, Papadopoulou A, Naik S, Leung K, Martinez CA, Ramos $\mathrm{CA}$, et al. Off-the-shelf virus-specific $\mathrm{T}$ cells to treat BK virus, human herpesvirus 6, cytomegalovirus, Epstein-Barr virus, and adenovirus infections after allogeneic hematopoietic stem-cell transplantation. J Clin Oncol. (2017) 35:3547-57. doi: 10.1200/JCO.2017.73.0655

37. Lilleri D, Gerna G, Zelini P, Chiesa A, Rognoni V, Mastronuzzi A, et al. Monitoring of human cytomegalovirus and virus-specific T-cell response in young patients receiving allogeneic hematopoietic stem cell transplantation. PLoS ONE. (2012) 7:e41648. doi: 10.1371/journal.pone.0041648

38. Alexandersson A, Koskenvuo M, Tiderman A, Lääperi M, Huttunen $\mathrm{P}$, Saarinen-Pihkala $U$, et al. Viral infections and immune reconstitution 
interaction after pediatric allogenic hematopoietic stem cell transplantation. Infect Dis. (2019) 51:772-8. doi: 10.1080/23744235.2019.1650198

39. Tan CS, Broge TA Jr, Ngo L, Gheuens S, Viscidi R, Bord E, et al. Immune reconstitution after allogeneic hematopoietic stem cell transplantation is associated with selective control of JC virus reactivation. Biol Blood Marrow Transplant. (2014) 20:992-9. doi: 10.1016/j.bbmt.2014.03.018

40. Hiwarkar P, Gaspar HB, Gilmour K, Jagani M, Chiesa R, Bennett-Rees N, et al. Impact of viral reactivations in the era of pre-emptive antiviral drug therapy following allogeneic haematopoietic SCT in paediatric recipients. Bone Marrow Transplant. (2013) 48:803-8. doi: 10.1038/bmt.2012.221

41. Papadopoulos EB, Ladanyi M, Emanuel D, Mackinnon S, Boulad F, Carabasi $\mathrm{MH}$, et al. Infusions of donor leukocytes to treat EpsteinBarr virus-associated lymphoproliferative disorders after allogeneic bone marrow transplantation. N Engl J Med. (1994) 330:1185-91. doi: 10.1056/NEJM199404283301703

42. Bonini C, Ferrari G, Verzeletti S, Servida P, Zappone E, Ruggieri $\mathrm{L}$, et al. HSV-TK gene transfer into donor lymphocytes for control of allogeneic graft-versus-leukemia. Science. (1997) 276:1719-24. doi: 10.1126/science.276.5319.1719

43. Di Stasi A, Tey SK, Dotti G, Fujita Y, Kennedy-Nasser A, Martinez C, et al. Inducible apoptosis as a safety switch for adoptive cell therapy. N Engl J Med. (2011) 365:1673-83. doi: 10.1056/NEJMoa1 106152

44. Heslop HE, Ng CY, Li C, Smith CA, Loftin SK, Krance RA, et al. Longterm restoration of immunity against Epstein-Barr virus infection by adoptive transfer of gene-modified virus-specific T lymphocytes. Nat Med. (1996) 2:551-5. doi: 10.1038/nm0596-551

45. Trivedi D, Williams RY, O’Reilly RJ, Koehne G. Generation of CMV-specific $\mathrm{T}$ lymphocytes using protein-spanning pools of pp65-derived overlapping pentadecapeptides for adoptive immunotherapy. Blood. (2005) 105:2793801. doi: 10.1182/blood-2003-05-1433

46. Vera JF, Brenner LJ, Gerdemann U, Ngo MC, Sili U, Liu H, et al. Accelerated production of antigen-specific $\mathrm{T}$ cells for preclinical and clinical applications using gaspermeable rapid expansion cultureware (G-Rex). J Immunother. (2010) 33:305-15. doi: 10.1097/CJI.0b013e3181c0c3cb

47. Khanna N, Stuehler C, Conrad B, Lurati S, Krappmann S, Einsele H, et al. Generation of a multipathogen-specific T-cell product for adoptive immunotherapy based on activation-dependent expression of CD154. Blood. (2011) 118:1121-31. doi: 10.1182/blood-2010-12-322610

48. Cobbold M, Khan N, Pourgheysari B, Tauro S, McDonald D, Osman H, et al. Adoptive transfer of cytomegalovirus-specific CTL to stem cell transplant patients after selection by HLA-peptide tetramers. J Exp Med. (2005) 202:37986. doi: $10.1084 /$ jem. 20040613

49. Peggs KS, Thomson K, Samuel E, Dyer G, Armoogum J, Chakraverty R, et al. Directly selected cytomegalovirus-reactive donor $\mathrm{T}$ cells confer rapid and safe systemic reconstitution of virus-specific immunity following stem cell transplantation. Clin Infect Dis. (2011) 52:49-57. doi: 10.1093/cid/ciq042

50. Icheva V, Kayser S, Wolff D, Tuve S, Kyzirakos C, Bethge W, et al. Adoptive transfer of Epstein-Barr virus (EBV) nuclear antigen 1-specific $\mathrm{T}$ cells as treatment for EBV reactivation and lymphoproliferative disorders after allogeneic stem-cell transplantation. J Clin Oncol. (2013) 31:3948. doi: 10.1200/JCO.2011.39.8495

51. Novy P, Quigley M, Huang X, Yang Y. CD4 T cells are required for CD8 T cell survival during both primary and memory recall responses. J Immunol. (2007) 179:8243-51. doi: 10.4049/jimmunol.179.12.8243

52. Heslop HE, Slobod KS, Pule MA, Hale GA, Rousseau A, Smith CA, et al. Long-term outcome of EBV-specific T-cell infusions to prevent or treat EBV related lymphoproliferative disease in transplant recipients. Blood. (2010) 115:925-35. doi: 10.1182/blood-2009-08-239186

53. Gustafsson A, Levitsky V, Zou JZ, Frisan T, Dalianis T, Ljungman P, et al. Epstein Barr virus (EBV) load in bone marrow transplant recipients at risk to develop posttransplant lymphoproliferative disease: prophylactic infusion of EBV-specific cytotoxic T cells. Blood. (2000) 95:80714. doi: 10.1182/blood.V95.3.807.003k24_807_814

54. Doubrovina E, Oflaz-Sozmen B, Prockop SE, Kernan NA, Abramson $\mathrm{S}$, Teruya-Feldstein J, et al. Adoptive immunotherapy with unselected or EBV-specific $\mathrm{T}$ cells for biopsy-proven EBV+lymphomas after allogeneic hematopoietic cell transplantation. Blood. (2012) 119:2644-56. doi: 10.1182/blood-2011-08-371971
55. Imashuku S, Goto $\mathrm{T}$, Matsumura $\mathrm{T}$, Naya $\mathrm{M}$, Yamori $\mathrm{M}$, Hojo $\mathrm{M}$, et al. Unsuccessful CTL transfusion in a case of post-BMT Epstein-Barr virus-associated lymphoproliferative disorder (EBV-LPD). Bone Marrow Transplant. (1997) 20:337-40. doi: 10.1038/sj.bmt.1700883

56. Jiang $\mathrm{X}, \mathrm{Xu} \mathrm{L}$, Zhang Y, Huang F, Liu D, Sun J, et al. Rituximab-based treatments followed by adoptive cellular immunotherapy for biopsy-proven EBV-associated post-transplant lymphoproliferative disease in recipients of allogeneic hematopoietic stem cell transplantation. Oncoimmunology. (2016) 5:e1139274. doi: 10.1080/2162402X.2016.1139274

57. Moosmann A, Bigalke I, Tischer J, Schirrmann L, Kasten J, Tippmer S, et al. Effective and long-term control of EBV PTLD after transfer of peptide-selected T cells. Blood. (2010) 115:2960-70. doi: 10.1182/blood-2009-08-236356

58. Einsele H, Roosnek E, Rufer N, Sinzger C, Riegler S, Löffler J, et al. Infusion of cytomegalovirus (CMV)-specific $\mathrm{T}$ cells for the treatment of CMV infection not responding to antiviral chemotherapy. Blood. (2002) 99:3916-22. doi: 10.1182/blood.V99.11.3916

59. Peggs KS, Verfuerth S, Pizzey A, Khan N, Guiver M, Moss PA, et al. Adoptive cellular therapy for early cytomegalovirus infection after allogeneic stemcell transplantation with virus-specific T-cell lines. Lancet. (2003) 362:13757. doi: $10.1016 / S 0140-6736(03) 14634-X$

60. Micklethwaite K, Hansen A, Foster A, Snape E, Antonenas V, Sartor $\mathrm{M}$, et al. Ex vivo expansion and prophylactic infusion of CMV-pp65 peptide specific cytotoxic T-lymphocytes following allogeneic hematopoietic stem cell transplantation. Biol Blood Marrow Transplant. (2007) 13:70714. doi: 10.1016/j.bbmt.2007.02.004

61. Bao L, Cowan MJ, Dunham K, Horn B, McGuirk J, Gilman A, et al. Adoptive immunotherapy with CMV-specific cytotoxic T lymphocytes for stem cell transplant patients with refractory CMV infections. J Immunother. (2012) 35:293-8. doi: 10.1097/CJI.0b013e31824300a2

62. Koehne G, Hasan A, Doubrovina E, Prockop S, Tyler E, Wasilewski G, et al. Immunotherapy with donor $\mathrm{T}$ cells sensitized with overlapping pentadecapeptides for treatment of persistent cytomegalovirus infection or viremia. Biol Blood Marrow Transplant. (2015) 21:1663-78. doi: 10.1016/j.bbmt.2015.05.015

63. Feuchtinger T, Opherk K, Bethge WA, Topp MS, Schuster FR, Weissinger EM, et al. Adoptive transfer of pp65-specific T cells for the treatment of chemorefractory cytomegalovirus disease or reactivation after haploidentical and matched unrelated stem cell transplantation. Blood. (2010) 116:43607. doi: 10.1182/blood-2010-01-262089

64. Meij P, Jedema I, Zandvliet ML, van der Heiden PL, van de Meent $M$, van Egmond $\mathrm{HM}$, et al. Effective treatment of refractory CMV reactivation after allogeneic stem cell transplantation with in vitro generated CMV pp65-specific CD8 T-cell lines. J Immunother. (2012) 35:6218. doi: 10.1097/CJI.0b013e31826e35f6

65. Schmitt A, Tonn T, Busch DH, Grigoleit GU, Einsele H, Odendahl M, et al. Adoptive transfer and selective reconstitution of streptamer-selected cytomegalovirus-specific CD8+T cells leads to virus clearance in patients after allogeneic peripheral blood stem cell transplantation. Transfusion. (2011) 51:591-9. doi: 10.1111/j.1537-2995.2010.02940.x

66. Feucht J, Opherk K, Lang P, Kayser S, Hartl L, Bethge W, et al. Adoptive T-cell therapy with hexon-specific Thl cells as a treatment of refractory adenovirus infection after HSCT. Blood. (2015) 125:198694. doi: 10.1182/blood-2014-06-573725

67. Ip W, Silva JMF, Gaspar H, Mitra A, Patel S, Rao K, et al. Multicenter phase 1/2 application of adenovirus-specific $\mathrm{T}$ cells in high-risk pediatric patients after allogeneic stem cell transplantation. Cytotherapy. (2018) 20:8308. doi: 10.1016/j.jcyt.2018.03.040

68. Qian C, Campidelli A, Wang Y, Cai H, Venard V, Jeulin H, et al. Curative or pre-emptive adenovirus-specific $\mathrm{T}$ cell transfer from matched unrelated or third party haploidentical donors after HSCT, including UCB transplantations: a successful phase I/II multicenter clinical trial. J Hematol Oncol. (2017) 10:102. doi: 10.1186/s13045-017-0469-0

69. Pello OM, Innes AJ, Bradshaw A, Finn SA, Uddin S, Bray E, et al. BKV specific $\mathrm{T}$ cells in the treatment of severe refractory haemorrhagic cystitis after HLAhaploidentical haematopoietic cell transplantation. Eur J Haematol. (2017) 98:632-4. doi: 10.1111/ejh.12848 
70. Haque T, Wilkie GM, Jones MM, Higgins CD, Urquhart G, Wingate P, et al. Allogeneic cytotoxic T-cell therapy for EBV-positive post-transplantation lymphoproliferative disease: results of a phase 2 multicenter clinical trial. Blood. (2007) 110:1123-31. doi: 10.1182/blood-2006-12-063008

71. Barker JN, Doubrovina E, Sauter C, Jaroscak JJ, Perales MA, Doubrovin M, et al. Successful treatment of EBV-associated posttransplantation lymphoma after cord blood transplantation using third-party EBV-specific cytotoxic T lymphocytes. Blood. (2010) 116:5045-9. doi: 10.1182/blood-2010-04-281873

72. Prockop S, Doubrovina E, Suser S, Heller G, Barker J, Dahi P, et al. Offthe-shelf EBV-specific T cell immunotherapy for rituximab-refractory EBVassociated lymphoma following transplantation. J Clin Invest. (2020) 130:73347. doi: $10.1172 / \mathrm{JCI} 121127$

73. Uhlin M, Gertow J, Uzunel M, Okas M, Berglund S, Watz E, et al. Rapid salvage treatment with virus-specific T cells for therapy resistant disease. Clin Infect Dis. (2012) 55:1064-73. doi: 10.1093/cid/cis625

74. Muftuoglu M, Olson A, Marin D, Ahmed S, Mulanovich V, Tummala S, et al. Allogeneic BK virus-specific $T$ cells for progressive multifocal leukoencephalopathy. N Engl J Med. (2018) 379:1443-51. doi: 10.1056/NEJMoa1801540

75. Leen AM, Myers GD, Sili U, Huls MH, Weiss H, Leung KS, et al. Monoculturederived $\mathrm{T}$ lymphocytes specific for multiple viruses expand and produce clinically relevant effects in immunocompromised individuals. Nat Med. (2006) 12:1160-6. doi: 10.1038/nm1475

76. Melenhorst JJ, Castillo P, Hanley PJ, Keller MD, Krance RA, Margolin J, et al. Graft versus leukemia response without graft-versus-host disease elicited by adoptively transferred multivirus-specific T-cells. Mol Ther. (2015) 23:17983. doi: 10.1038/mt.2014.192

77. Leen AM, Christin A, Myers GD, Liu H, Cruz CR, Hanley PJ, et al. Cytotoxic $\mathrm{T}$ lymphocyte therapy with donor $\mathrm{T}$ cells prevents and treats adenovirus and Epstein-Barr virus infections after haploidentical and matched unrelated stem cell transplantation. Blood. (2009) 114:428392. doi: 10.1182/blood-2009-07-232454

78. Dong L, Gao ZY, Chang LJ, Liang Y, Tan XY, Liu JH, et al. Adoptive transfer of cytomegalovirus/Epstein-Barr virus specific immune effector cells for therapeutic and preventive/preemptive treatment of pediatric allogeneic cell transplant recipients. J Pediatr Hematol Oncol. (2010) 32:e317. doi: 10.1097/MPH.0b013e3181bf5e2d

79. Gerdemann U, Katari UL, Papadopoulou A, Keirnan JM, Craddock JA, Liu $\mathrm{H}$, et al. Safety and clinical efficacy of rapidly-generated trivirusdirected $\mathrm{T}$ cells as treatment for adenovirus, EBV, and CMV infections after allogeneic hematopoietic stem cell transplant. Mol Ther. (2013) 21:211321. doi: 10.1038/mt.2013.151

80. Papadopoulou A, Gerdemann U, Katari UL, Tzannou I, Liu H, Martinez $\mathrm{C}$, et al. Activity of broad-spectrum $\mathrm{T}$ cells as treatment for AdV, EBV, CMV, BKV, and HHV6 infections after HSCT. Sci Transl Med. (2014) 6:242ra283. doi: 10.1126/scitranslmed.3008825

81. Ma CK, Blyth E, Clancy L, Simms R, Burgess J, Brown R, et al. Addition of varicella zoster virus-specific $\mathrm{T}$ cells to cytomegalovirus, Epstein-Barr virus and adenovirus tri-specific $\mathrm{T}$ cells as adoptive immunotherapy in patients undergoing allogeneic hematopoietic stem cell transplantation. Cytotherapy. (2015) 17:1406-20. doi: 10.1016/j.jcyt.2015.07.005

82. Hanley PJ, Melenhorst JJ, Nikiforow S, Scheinberg P, Blaney JW, DemmlerHarrison G, et al. CMV-specific T cells generated from naive T cells recognize atypical epitopes and may be protective in vivo. Sci Transl Med. (2015) 7:285ra263. doi: 10.1126/scitranslmed.aaa2546

83. Naik S, Nicholas SK, Martinez CA, Leen AM, Hanley PJ, Gottschalk SM, et al. Adoptive immunotherapy for primary immunodeficiency disorders with virus-specific T lymphocytes. J Allergy Clin Immunol. (2016) 137:1498505.e1. doi: 10.1016/j.jaci.2015.12.1311

84. Leen AM, Bollard CM, Mendizabal AM, Shpall EJ, Szabolcs P, Antin JH, et al. Multicenter study of banked third-party virus-specific T cells to treat severe viral infections after hematopoietic stem cell transplantation. Blood. (2013) 121:5113-23. doi: 10.1182/blood-2013-02-486324
85. Rooney CM, Smith CA, Ng CY, Loftin SK, Sixbey JW, Gan Y, et al. Infusion of cytotoxic T cells for the prevention and treatment of Epstein-Barr virusinduced lymphoma in allogeneic transplant recipients. Blood. (1998) 92:154955. doi: 10.1182/blood.V92.5.1549

86. Di Nardo M, Li Pira G, Amodeo A, Cecchetti C, Giorda E, Ceccarelli S, et al. Adoptive immunotherapy with antigen-specific $\mathrm{T}$ cells during extracorporeal membrane oxygenation (ECMO) for adenovirus-related respiratory failure in a child given haploidentical stem cell transplantation. Pediatr Blood Cancer. (2014) 61:376-9. doi: 10.1002/pbc.24753

87. Perruccio K, Sisinni L, Perez-Martinez A, Valentin J, Capolsini I, Massei MS, et al. High incidence of early human herpesvirus6 infection in children undergoing haploidentical manipulated stem cell transplantation for hematologic malignancies. Biol Blood Marrow Transplant. (2018) 24:2549-57. doi: 10.1016/j.bbmt.2018. 07.033

88. Basar R, Daher M, Uprety N, Gokdemir E, Alsuliman A, Ensley E, et al. Large-scale GMP-compliant CRISPR-Cas9-mediated deletion of the glucocorticoid receptor in multivirus-specific T cells. Blood Adv. (2020) 4:3357-67. doi: 10.1182/bloodadvances.2020001977

89. De Angelis B, Dotti G, Quintarelli C, Huye LE, Zhang L, Zhang M, et al. Generation of Epstein-Barr virus-specific cytotoxic T lymphocytes resistant to the immunosuppressive drug tacrolimus (FK506). Blood. (2009) 114:478491. doi: 10.1182/blood-2009-07-230482

90. Ricciardelli I, Blundell MP, Brewin J, Thrasher A, Pule M, Amrolia PJ. Towards gene therapy for EBV-associated posttransplant lymphoma with genetically modified EBV-specific cytotoxic T cells. Blood. (2014) 124:251422. doi: 10.1182/blood-2014-01-553362

91. Montagna D, Maccario R, Locatelli F, Rosti V, Yang Y, Farness P, et al. Ex vivo priming for long-term maintenance of antileukemia human cytotoxic $\mathrm{T}$ cells suggests a general procedure for adoptive immunotherapy. Blood. (2001) 98:3359-66. doi: 10.1182/blood.V98.12.3359

92. Comoli P, Ginevri F, Maccario R, Frasson C, Valente U, Basso S, et al. Successful in vitro priming of EBV-specific CD8+ T cells endowed with strong cytotoxic function from $\mathrm{T}$ cells of EBV-seronegative children. Am J Transplant. (2006) 6:2169-76. doi: 10.1111/j.1600-6143.2006.01429.x

93. Savoldo B, Cubbage ML, Durett AG, Goss J, Huls MH, Liu Z, et al. Generation of EBV-specific CD4+ cytotoxic T cells from virus naive individuals. $J$ Immunol. (2002) 168:909-18. doi: 10.4049/jimmunol.168.2.909

94. Popescu I, Macedo C, Zeevi A, Nellis J, Patterson KR, Logar A, et al. Ex vivo priming of naïve $\mathrm{T}$ cells into EBV-specific Th1/Tc1 effector cells by mature autologous DC loaded with apoptotic/necrotic LCL. Am J Transplant. (2003) 3:1369-77. doi: 10.1046/j.1600-6135.2003.00252.x

95. Faraci M, Lanino E, Micalizzi C, Morreale G, Di Martino D, Banov L, et al. Unrelated hematopoietic stem cell transplantation for Cernunnos-XLF deficiency. Pediatr Transplant. (2009) 13:785-9. doi: 10.1111/j.1399-3046.2008.01028.x

96. Qasim W, Derniame S, Gilmour K, Chiesa R, Weber M, Adams S, et al. Third-party virus-specific $\mathrm{T}$ cells eradicate adenoviraemia but trigger bystander graft-versus host disease. Br J Haematol. (2011) 154:1503. doi: 10.1111/j.1365-2141.2011.08579.x

Conflict of Interest: The authors declare that the research was conducted in the absence of any commercial or financial relationships that could be construed as a potential conflict of interest.

Copyright (C) 2020 Basso, Compagno, Zelini, Giorgiani, Boghen, Bergami, Bagnarino, Siciliano, Del Fante, Luppi, Zecca and Comoli. This is an open-access article distributed under the terms of the Creative Commons Attribution License (CC BY). The use, distribution or reproduction in other forums is permitted, provided the original author(s) and the copyright owner(s) are credited and that the original publication in this journal is cited, in accordance with accepted academic practice. No use, distribution or reproduction is permitted which does not comply with these terms. 